\title{
Why do females choose to study humanities or social sciences, while males prefer technology or science? Some intrapersonal and interpersonal predictors
}

\author{
Sławomir Trusz ${ }^{1}$ (D) \\ Received: 4 October 2018 / Accepted: 12 March 2020 / Published online: 18 April 2020 \\ (c) The Author(s) 2020
}

\begin{abstract}
The article attempts to answer the question why females prefer humanities/social studies, whereas males opt for technology/science. For this purpose, the study majors selected by 445 females and 431 males were linked by logit functions with: (1) parents' and (2) teachers' expectancies, (3) students' self-expectancies, (4) their self-concepts of abilities and (5) time spent on learning mathematics and (6) literacy, (7) test results in mathematics and (8) literacy, (9) gender of mathematics, and (10) literacy teacher in the 12th grade. Interaction effects of the mathematics and literacy teacher's gender with the abovementioned predictors were also quantified. Females' selections were mostly influenced by teachers' expectancies, while for males, by their self-concepts. The teacher's gender modified tested relations in five (females) and nine (males) cases. The results were discussed on the grounds of the theory of intra- and interpersonal expectancies as learning regulators.
\end{abstract}

Keywords Gender stereotype · Interpersonal and intrapersonal expectancies · Educational achievement of females and males

\section{Introduction}

Are girls actually more polite and hard-working than boys, and boys more aggressive and pugnacious than girls? Feminists say not, arguing that gender stereotypes are sources of significant differences in behavior, and later, in educational attainment of students. Gender stereotypes, i.e., unjustified representations of various groups of people, by definition omitting any differences between them (Kite and Whitley 2016; Stangor 2009), may incline parents and teachers to treat their daughters (female students) and sons (male students) differently.

Sławomir Trusz

trusz@up.krakow.pl

1 Institute of Educational Sciences, Pedagogical University of Kraków, 4 Ingardena St.,

30-060 Kraków, Poland 
Teachers at school may encourage male students to learn science more, e.g., by praising them for their correctly conducted physical experiments, whereas female students might be motivated to analyze the beauty of Gabriele Mistral's poetry, according to socially shared schema of technically talented boys and humanistically predisposed girls (Eccles et al. 1990; Jussim et al. 1996; Watson et al. 2017). Similarly, at home, parents who keep their daughters away from screwdrivers or their sons away from dolls may show them how to bake cakes and replace a bicycle hub, respectively (Jacobs et al. 2004; Simpkins et al. 2018).

The noticeable gap in educational experience and performance of schematically male versus female subjects among students cannot be explained solely by their abilities (individual differences), but to some extent also by the cultural transmission of gender stereotypes (e.g., Li 1999; Nguyen and Ryan 2008; Robnett 2016; Spencer et al. 1999; Tiedemann 2000; Watson et al. 2017).

In terms of this gap, the importance of expectations of significant others on the typical behavior of girls and boys, and correlated children's self-expectations (e.g., Pajares and Miller 1994; Rudman and Phelan 2010; Trusz 2018), their self-concept of ability in humanities/social studies (H/SS) versus technology/science (T/S) (e.g., Sullivan 2009; Szumski and Karwowski 2019; Trusz 2018), and time spent on gender-stereotyped and gender-neutral activities must be emphasized (e.g., Debacker and Nelson 2000; Hyde 2014; Plante et al. 2019).

As a result, initially inaccurate gender stereotypes may be the source of real differences in the functioning of females and males, sized according to a specific domain of human activity. The reason for this is provided by the results of meta-analyses in which the average sizes of the gender effect for mathematical performance were Cohen's $\mathrm{d}=-.11$ (Else-Quest et al. 2010), .16 (Lindberg et al. 2010), .22 (Reilly 2012), .29 and .32 (Hyde et al. 1990), .43 (Hyde 1990); for cognitive abilities, e.g., mental rotation, were .51 (Voyer 2011), .56 (Voyer et al. 1995), 1.03 (Voyer 2011); for literacy performance were - .11 (Hyde and Linn 1988), - .37 (Voyer and Voyer 2014), - .44 (Reilly 2012); for academic (Huang 2013) and global self-efficacy (Kling et al. 1999), were .08 and .21, respectively; for leadership were -.13, .16, and .27 (Eagly et al. 2003); and for prosocial behavior was .37 (Eagly 2009). Negative values of Cohen's d represent higher female results than male ones in the tested domain.

An important mechanism of this transformation seems to be the stereotype threat (e.g., Nguyen and Ryan 2008; Schmader 2002; Shapiro and Williams 2012) and selffulfilling prophecy (e.g., Fiedler et al. 2002; Gentrup and Rjosk 2018; Watson et al. 2017). The indicated phenomena, together with the regulatory function of students' self-expectations and their self-concept of ability in T/S and H/SS (e.g., Fan 2011; Rudman and Phelan 2010; Szumski and Karwowski 2019) are discussed in more detail in the following sections of this paper.

\subsection{Teachers' and parents' expectancies related to females' and males' achievement}

Gender stereotypes are sources of varied expectancies concerning the social behavior and educational achievement of females and males. In the case of social 
behavior, teachers and parents expect females to be more submissive, warm, and protective than males. In contrast, a prototype male should be dynamic, successful, and tough (Eccles et al. 1990; Kite and Whitley 2016). Hall and Briton (1993) identified representative gender-stereotypical adjectives. The authors claim that "in general masculine and feminine traits fall into two categories: agentic or instrumental for the masculine and expressive or communal for feminine" (p. 278).

Different expectancies also apply to educational achievement of female and male students (Jussim et al. 1996; Simpkins et al. 2006). If females are more emotional and warmer, they should present higher scores in H/SS classes, the masculine, analytical, and lively males' minds allegedly predispose them to achieve higher results in $\mathrm{T} / \mathrm{S}$ classes.

Through the analysis of the achievements in mathematics of mid-grade female students at primary school, Tiedemann (2000) showed that they are significantly differentiated by their mothers' and fathers' gender stereotype-tinged expectancies, as well as by the transformation of the children's self-concept of mathematical ability caused by parents' bias perception. Parents who believed in the stereotype, as opposed to those immune to its impact, assigned lower mathematical abilities (but not the effort put into learning) to their daughters than their sons. Commenting on the obtained results, the author underlines: "although the effects are not large, they are consistent, and they appear to influence children's self-perceptions in a manner consistent with the self-fulfilling prophecy hypothesis" ( $p$. 149). Analogous results were revealed for gender stereotype-tinged expectancies.

In the next study, involving a similar age structure sample, McKown and Weinstein (2002) found that girls were more than 3.5 times as likely to confirm teachers' low expectancies on their mathematics ability compared to high expectancies. In contrast, boys were only about 0.5 times as likely to confirm teachers' low compared to high expectancies. Furthermore, the power of the identified trend intensified as the age of students increased. A similar impact of the gender stereotype did not occur in the case of students' literary achievements.

Expectancies of others based on gender stereotypes may affect students' educational achievement and subsequently their selection of T/S versus H/SS courses and majors. Hattie (2009), based on meta-analysis of 674 studies, calculated that the average effect size of expectancies for students' educational achievement was $d=.43$. This means that about $35 \%$ of students show higher or lower academic performance than would be predicted based on other factors than teachers' expectancies.

It seems that consistent communication of teachers' expectancies related to gender stereotypes reflected in preferential treatment of females and males in arts and mathematics classes, respectively, may lead the former to select H/SS majors and the latter T/S ones (Harris and Rosenthal 1985; Rubie-Davies 2015).

However, it is hardly known to what extent the transmission of gender stereotypetinged expectancies of significant others occurs specifically in diades of the same versus different sexes (i.e., from teacher/parent man/woman to girl/boy vs. from teacher/parent man/woman to boy/girl). The available evidence is not conclusive (Brophy and Good 1974; Bernard et al. 1981; Rubie-Davies 2015). 


\subsection{Students' self-expectancies concerning typically female and male activities}

Gender stereotypes are the source of interpersonal expectancies and, on the other hand, of students' expectancies about themselves. By asking questions such as "What am I good at?" and "What subjects should I learn?" children seek answers through the analysis of parents' and teachers' expectancy-tinged communications (Babad 2009; Cvencek et al. 2011; Darley and Fazio 1980). Therefore, boys who are socialized to fulfill roles typically attributed to males know that activities including emotional involvement are appropriate for girls and that they should stop themselves from crying even though they have a broken knee hurts a great deal. On the other hand, girls are aware that climbing trees is not the kind of activity that "ladies" do, whereas feeling sorry for people in need is.

For instance, Pajares and Miller (1994) found a strong link between students' judgments about their capability to solve math problems and their mathematics achievement. Therefore, self-efficacy mediated the effect of gender and prior experience on mathematics self-concept, and then on mathematics problem-solving performance. Male and female students differed in mathematics performance, self-efficacy, and self-concept, and these differences were mediated by differences in the students' self-efficacy perceptions. It should be emphasized that lower performance and more negative self-concept of the female students were largely determined by lower judgments of their capabilities. Similar results, in more recent studies, were obtained by Plante et al. (2019), Rudman and Phelan (2010), Szumski and Karwowski (2019), and Trusz (2018).

To sum up, interpersonal expectancy effects can be regulated by students' self-expectancies and self-concepts of abilities. The indicated factors connect the expectancies of significant others with students' achievement, and at the same time, directly influence their educational careers (Trusz 2018; Rubie-Davies 2006; Tosto et al. 2016; Wigfield and Eccles 2000). Consequently, inter and intrapersonal stereotype-tinged expectancies may influence the results of the matriculation tests and subsequent selection of study majors made by females and males.

\subsection{The self-fulfilling prophecy mechanism and gender-stereotype threat in relation to educational achievement of females and males}

Different educational and professional careers of females and males, despite similar input level of intellectual abilities (Hyde 2005), can be explained by two mechanisms: the self-fulfilling prophecy and the gender stereotype threat.

The first mechanism occurs when a parent or teacher creates false expectancies concerning individual characteristics of a child (e.g., my daughter is sensitive so in the future she will choose to study humanities vs. my son solves logical rebuses easily, so in the future he will study at the university of technology). Afterwards, these expectancies are communicated to the child through the parent's/teacher's verbal and nonverbal behavior. Finally, despite the original inappropriateness, the expectancies are confirmed - the female actually selects a H/SS major and the male goes for a T/SS one (Trusz and Bąbel 2016; Rubie-Davies 2015). 
Realization of these false expectancies is facilitated if they are accepted by children and, consequently, incorporated into the self-schemas system, i.e., self-expectancies and self-concepts of abilities (Jussim 1986; Jussim and Eccles 1995; RubieDavies 2006). This is possible as a result of the stereotype threat mechanism. In the Spencer et al. experiment (1999), a group of females and males solved a mathematics test. Participants were informed either that the tasks were difficult and males should perform better due to allegedly higher analytical reasoning abilities (study 1), or that the tasks were easy (study 2).

It turned out that alleviating the stereotype threat in study 2 caused females to perform at a similar level to males. In contrast, providing information that tasks are difficult for females induced an aversive affect and intense intellectual overstimulation, which paradoxically, as a result of emotional and cognitive overload, undermined females' outcomes as opposed to relaxed males.

The discussed results were replicated in a series of studies (e.g., Aronson and McGlone 2009; Schmader 2002; Shapiro and Williams 2012; Tomasetto et al. 2011). After all, in a Nguyen and Ryan's (2008) meta-analysis, based on the results of 116 studies, the average size of the stereotype threat effect for women's mathematical achievements was Cohen's $d=.26$. Moreover, the authors demonstrated that the negative impact of the analyzed phenomenon is strongest for moderately mathematics-identified women (.52), followed by highly mathematics-identified women (.29) and low mathematics-identified women (.11).

\subsection{Learning effort and earlier outcomes as predictors of educational achievement}

In addition to socially constructed factors of educational achievement, i.e., inter- and intrapersonal expectancies (de Boer et al. 2010; Rubie-Davies 2015), the educational outcomes, and consequently females' and males' selections of study majors are also influenced by objective variables, i.e., time invested in learning and results obtained in particular subjects.

In a meta-analysis of 100 studies, Hattie (2009) calculated that the average effect size of learning time on academic success was $d=.38$. This means that about $30 \%$ of students present higher or lower results than would have been predicted based on factors other than the various times they spent on learning. Similarly, based on 3607 studies, the same author calculated that average effect size of prior achievement for academic success was $d=.67$. This shows that about $35 \%$ of students present a higher increase or decrease in academic results than could have been expected based on promises other than their prior achievement.

It seems that people who invest more time in learning literacy versus mathematics and obtain higher results in matriculation tests in these subjects should be more likely to select H/SS versus T/S majors, respectively (Meece et al. 2009).

Eurostat data (2017) confirm a noticeable imbalance between males and females studying T/S majors (from 61 to $74 \%$ of males) and between females and males studying H/SS majors (from 58 to $78 \%$ of females). Similar results are reported for nonEuropean countries, e.g., Canada, USA, Australia, India, and Japan (cf. Catalyst 2018). 
The aforementioned difference can be explained partly by the results achieved in standardized tests - for female students higher in literacy and for male students higher in mathematics (Machin and Pekkarinen 2008) — as well as by the impact of gender stereotype-tinged expectancies of parents and teachers, students' selfexpectancies, and their self-concepts (Rudman and Phelan 2010; Starr and Leaper 2019; Szumski and Karwowski 2019; Tiedemann 2000; Watson et al. 2017). Moreover, relations between the indicated factors and the study majors selected by $\mathrm{K}-12$ students may be significantly modified by the gender of mathematics and literacy teachers during the final year of secondary school (Brophy and Good 1974; Bernard et al. 1981; Rubie-Davies 2015).

\section{Objectives}

In the current study, an attempt was made to: (1) establish factors that make female students give preference to H/SS versus T/S majors, (2) establish factors that make male students give preference to T/S versus H/SS majors, and (3) test whether relations between the established predictors and the study majors chosen by females and males are modified by the gender of mathematics and literacy class teachers.

The study assumed that educational paths of females and males can be influenced by two groups of factors: (1) variables related to stereotypical beliefs on which study majors are appropriate for females and males, and (2) objective variables-with opposite vector-affecting academic performance. The first group included: parents' and the teacher's expectancies regarding children/students' achievement in mathematics and literacy, students' self-expectancies, and their self-concepts of abilities and predicted successes in exams in these subjects.

The second group included: the results of mathematics and literacy sections of the matriculation test (equivalent to the Scholastic Assessment Test or American College Testing in the USA) taken five months earlier in secondary school (scale from 0 to 100 points, with a 30-point grade threshold) and average daily time (in minutes) spent on learning mathematics and literacy prior to taking the matriculation test in these subjects. Test results and time of learning particular subjects reflect the effort invested in learning and correlate with predispositions of people to study them (Good and Brophy 2008; Wentzel and Wigfield 2009). Moreover, the mathematics and literacy tests results are critical for admission to university. The study also assumed that the relations between factors from groups $1 / 2$ and the outcome variable (selection of T/S vs. H/SS majors) could be modified by the gender of mathematics and literacy teacher in the final grade of secondary school.

To summarize, in the current study, two models were tested in which the outcome variable was the study major selected by females (model 1) and males (model 2 ), and predictors were: (1) parents' expectancies concerning their child achievement in mathematics and (2) literacy, (3) the teacher's expectancies regarding their students' achievement in mathematics and (4) literacy, (5) students' self-expectancies concerning matriculation test results in mathematics and (6) literacy, (7) their self-concept of mathematical and (8) literacy abilities, (9) the average declared time spent on learning mathematics and (10) literacy per day, (11) declared results in the 
mathematics and (12) literacy sections of the matriculation test, and (13) gender of the mathematics and (14) literacy teacher in the final grade of secondary school.

\section{Method}

\subsection{Participants}

The sample was organized using a convenience-voluntary sampling scheme (Weathington et al. 2010). The sample included participants who: (1) provided a written consent to participate in the study, (2) were first-year students of H/SS (e.g., sociology) or T/S majors (e.g., biochemistry), and (3) graduated from secondary school and successfully passed the matriculation exams in the same calendar year, i.e., 2017, when the investigation was conducted.

The study involved 876 subjects (445 females), first-year students (average age was 19.492; SD =.621) of different faculties in H/SS $(n=438 ; 220$ females $)$ and exact T/S $(\mathrm{n}=438 ; 220$ females) of universities located in a large southeast, well-industrialized region of Poland. The aims, procedure, and materials used in the study were approved by the Ethics Committee for Research at the Pedagogical University in Kraków.

\subsection{Materials}

Variables included in the tested models were controlled by means of a questionnaire developed by the paper's author. The tool consists of four parts containing statements assessed on a 4-point scale coded 1 (definitely inaccurate) to 4 (definitely accurate). Table 1 summarizes the assessment of questionnaire reliability.

Furthermore, the questionnaire included the following respondent details: (1) gender (coded: Male =1; Female=2) and (2) age of participant, (3) study majors (coded: $\mathrm{H} / \mathrm{SS}=0 ; \mathrm{T} / \mathrm{S}=1$ ), (4) year of college, (5) result in the mathematics and (6) literacy section of the matriculation test, (7) time spent on learning mathematics and (8) literacy (reported in minutes per day), and (9) gender of the mathematics and (10) literacy teacher in the final grade of secondary school.

\subsection{Research procedure}

The study was conducted individually. On the campuses of the universities where the subjects studied, e.g., in libraries, canteens, university corridors, during breaks between classes, in dormitories etc., the assistants of the principal investigator asked the subjects to complete the questionnaires. Having obtained the participant's written consent, the interviewer provided the respondent with appropriate forms and waited for him or her to complete them. If the participant requested additional information on the aims of the study, the interviewer provided a standard answer pointing out that "it concerns circumstances related to the subject's selection of study major, e.g., their parents and the teacher's beliefs on their mathematical and literacy abilities, the time spent on learning various subjects, their own interests, etc.". 


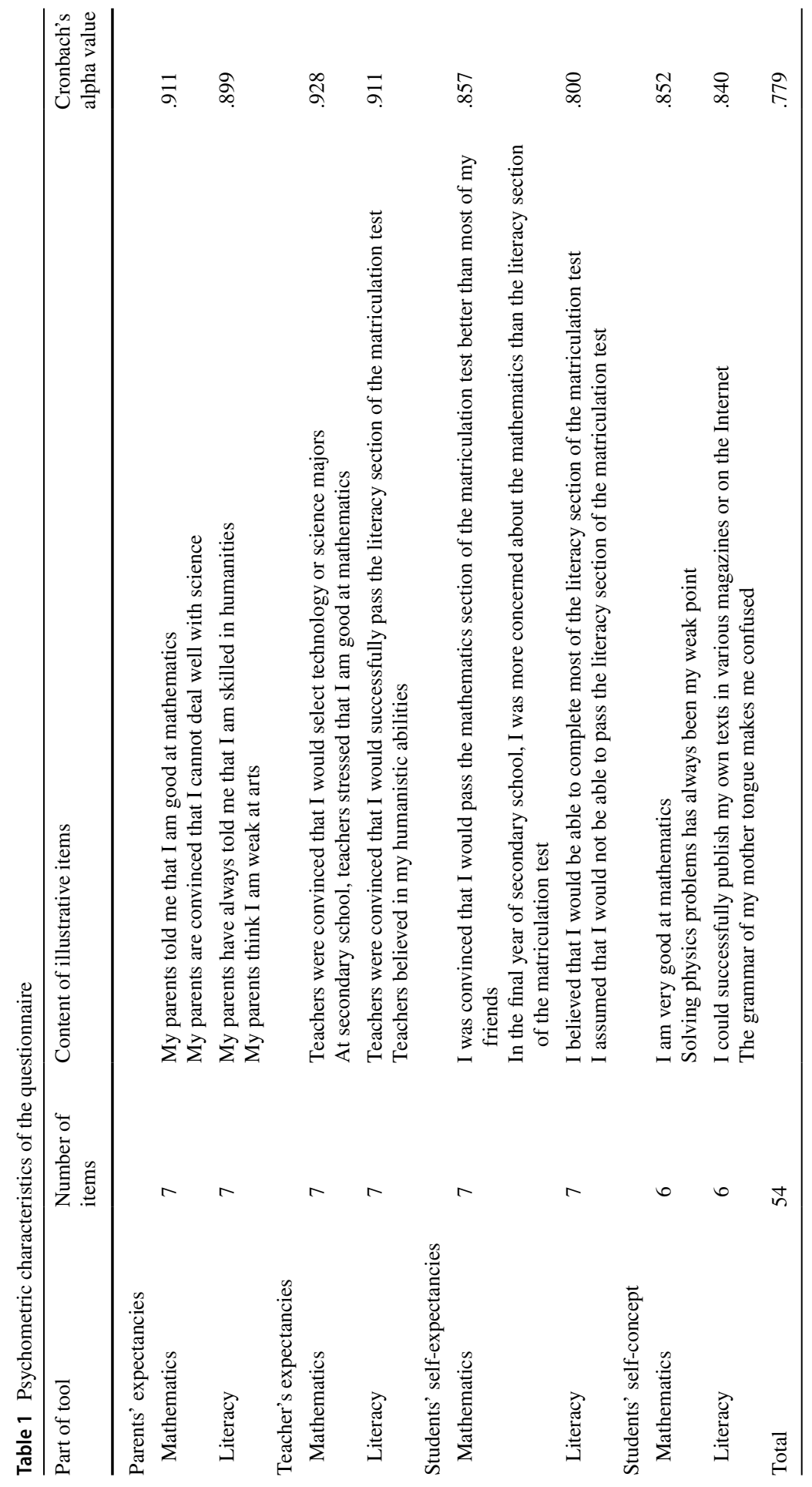




\section{Results}

\subsection{Preliminary data analysis}

Basic descriptive statistics of predictors included in the models are summarized in Table 2, and Table 3 shows correlations among them.

Before quantifying the models, outliers were excluded from the sample. Considering leverage values (above .085) and Cook's distances (above 1.00), data of 38

Table 2 Descriptive statistics of predictors included in models within the group of females and males

\begin{tabular}{|c|c|c|c|c|c|c|c|}
\hline \multirow[t]{2}{*}{ Predictors } & \multicolumn{7}{|c|}{ Descriptive statistics } \\
\hline & Min & Max & Mean & SEM & SD & Kurtosis & Skewness \\
\hline \multicolumn{8}{|l|}{ Females } \\
\hline Parents' expectancies-mathematics & 1 & 4 & 2.815 & .040 & .834 & -.214 & -1.056 \\
\hline Parents' expectancies-literacy & 1 & 4 & 2.922 & .037 & .775 & -.255 & -.904 \\
\hline Teacher's expectancies-mathematics & 1 & 4 & 2.536 & .041 & .865 & .052 & -1.040 \\
\hline Teacher's expectancies-literacy & 1 & 4 & 2.668 & .039 & .813 & .004 & -.993 \\
\hline $\begin{array}{l}\text { Students' self-expectancies-mathemat- } \\
\text { ics }\end{array}$ & 1 & 4 & 2.693 & .037 & .769 & -.148 & -.856 \\
\hline Students' self-expectancies-literacy & 1 & 4 & 2.953 & .030 & .638 & -.472 & -.221 \\
\hline Students' self-concept-mathematics & 1 & 4 & 2.536 & .038 & .795 & .029 & -.954 \\
\hline Students' self-concept-literacy & 1 & 4 & 2.554 & .029 & 609 & -.101 & -.843 \\
\hline Time spent on learning_-mathematics & 0 & 250 & 65.236 & 2.211 & 46.387 & 1.664 & 3.246 \\
\hline Time spent on learning-literacy & 0 & 360 & 45.972 & 1.957 & 41.049 & 2.589 & 10.971 \\
\hline $\begin{array}{l}\text { Results of the matriculation test-math- } \\
\text { ematics }\end{array}$ & 30 & 100 & 69.769 & .990 & 20.758 & -.251 & -1.086 \\
\hline $\begin{array}{l}\text { Results of the matriculation test-lit- } \\
\text { eracy }\end{array}$ & 30 & 100 & 73.034 & .670 & 14.063 & -.471 & .047 \\
\hline \multicolumn{8}{|l|}{ Males } \\
\hline Parents' expectancies-mathematics & 1 & 4 & 2.782 & .040 & .837 & -.242 & -1.005 \\
\hline Parents' expectancies-literacy & 1 & 4 & 2.736 & .037 & .769 & -.003 & -.872 \\
\hline Teacher's expectancies-mathematics & 1 & 4 & 2.534 & .043 & .889 & .074 & -1.096 \\
\hline Teacher's expectancies-literacy & 1 & 4 & 2.524 & .039 & .808 & .147 & -.916 \\
\hline $\begin{array}{l}\text { Students' self-expectancies-mathemat- } \\
\text { ics }\end{array}$ & 1 & 4 & 2.733 & .036 & .750 & -.091 & -.897 \\
\hline Students' self-expectancies_-literacy & 1 & 4 & 2.908 & .029 & .605 & -.149 & -.517 \\
\hline Students' self-concept-mathematics & 1 & 4 & 2.641 & .039 & .812 & -.024 & -1.097 \\
\hline Students' self-concept-literacy & 1 & 4 & 2.497 & .030 & .630 & -.017 & -1.017 \\
\hline Time spent on learning-mathematics & 0 & 270 & 52.782 & 1.994 & 41.630 & 1.591 & 3.977 \\
\hline Time spent on learning-literacy & 0 & 240 & 36.501 & 1.725 & 36.011 & 1.993 & 5.362 \\
\hline $\begin{array}{l}\text { Results of the matriculation test-math- } \\
\text { ematics }\end{array}$ & 30 & 100 & 69.311 & 1.002 & 20.920 & -.201 & -1.218 \\
\hline $\begin{array}{l}\text { Results of the matriculation test-lit- } \\
\text { eracy }\end{array}$ & 30 & 100 & 70.731 & .730 & 15.248 & -.224 & -.563 \\
\hline
\end{tabular}

All statistics are calculated on the basis of data collected from 876 subjects; SE of the kurtosis and skewness for all predictors $=.233$ and .117 , respectively 


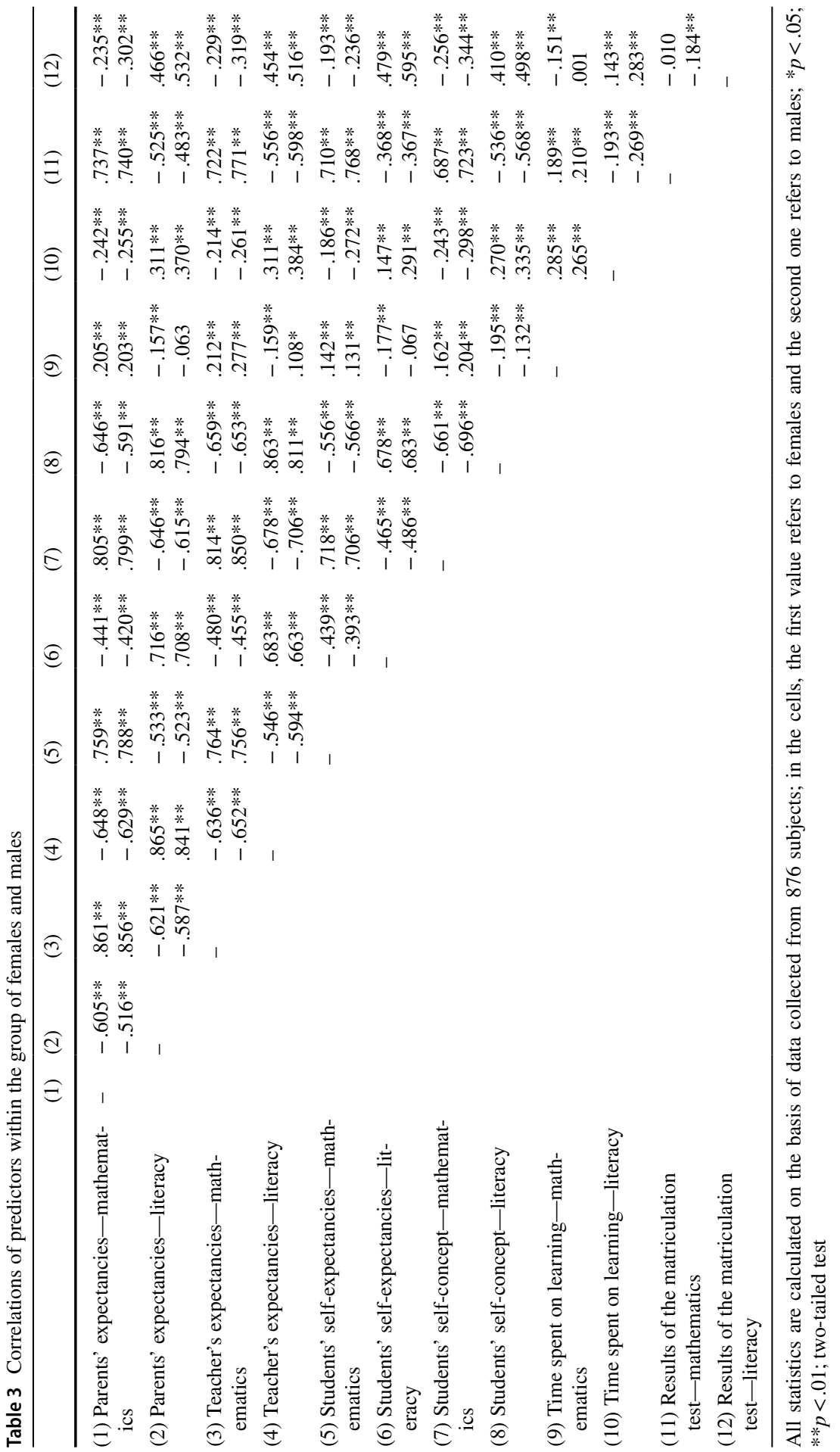


females and 41 males were excluded from the analysis. Ultimately, the models were tested based on materials obtained from 402 females and 395 males.

The relationships between the predictors and the outcome variable were linear (RESET test value for females was 1.288 , df1 $=28$, df $2=365, p>.05$ and for males was 1.410 , df $1=28, \mathrm{df} 2=352, p>.05)$. Tested models met the assumption that the predictors were not collinear (VIF statistics for females below 6.135 and tolerance above .163; and for males below 6.198 and above .161, respectively). All statistics presented in the paper were conducted using IBM SPSS Statistics 22 and R version 3.1.0 software.

\subsection{Predictors of the selection of study majors among females and males}

The assumed models were tested using logistic regression analysis. Tables 4 and 5 summarize the results obtained for females and males (non-significant predictors have been excluded from the analyses).

Table 4 Significant predictors of selecting T/S versus H/SS majors among females

\begin{tabular}{|c|c|c|c|c|c|c|c|}
\hline & $\mathrm{b}$ & S.E & Wald & $t(395)$ & $\exp (b)$ & \multicolumn{2}{|c|}{$\begin{array}{l}95 \% \text { CI for } \\
\exp (\mathrm{b})\end{array}$} \\
\hline Intercept & 1.861 & 1.472 & 1.597 & & 6.428 & & \\
\hline Parents' expectancies-literacy & $-1.314 * *$ & .451 & 8.475 & 2.911 & .269 & .111 & 651 \\
\hline Teacher's expectancies-mathematics & $1.684 * *$ & .350 & 23.178 & 4.813 & 5.388 & 2.714 & 10.695 \\
\hline Teacher's expectancies_literacy & $-2.008 * *$ & .445 & 20.370 & 4.512 & .134 & .056 & .321 \\
\hline Students' self-expectancies-mathematics & $-.871 *$ & .371 & 5.518 & 2.348 & .418 & .202 & .866 \\
\hline Students' self-expectancies_-literacy & $1.287 * *$ & .396 & 10.536 & 3.245 & 3.622 & 1.665 & 7.879 \\
\hline $\begin{array}{l}\text { Results of the matriculation test-math- } \\
\text { ematics }\end{array}$ & $.023 *$ & .012 & 3.836 & 1.958 & 1.024 & .999 & 1.049 \\
\hline
\end{tabular}

$* p<.05 ; * * p<.01$; Hosmer and Lemeshow $\chi^{2}(8)=9.991 ; \mathrm{p}$ ns.; -2 Log likelihood=247.495; Cox and Snell $\mathrm{R}^{2}=.537$; Nagelkerke $\mathrm{R}^{2}=.716 ; \mathrm{AIC}=261.495$

Table 5 Significant predictors of selecting T/S versus H/SS majors among males

\begin{tabular}{|c|c|c|c|c|c|c|c|}
\hline & $\mathrm{b}$ & S.E. & Wald & $\mathrm{t}(388)$ & $\exp (b)$ & \multicolumn{2}{|c|}{$\begin{array}{l}95 \% \text { CI for } \\
\exp (b)\end{array}$} \\
\hline Intercept & -1.209 & 1.647 & .539 & & .298 & & \\
\hline Teacher's expectancies-literacy & $-.804 *$ & .374 & 4.618 & 2.149 & .448 & .215 & .932 \\
\hline Students' self-concept-mathematics & $1.293 * *$ & .342 & 14.321 & 3.784 & 3.643 & 1.865 & 7.118 \\
\hline Students' self-concept-literacy & $-.950 *$ & .445 & 4.545 & 2.132 & .387 & .161 & .926 \\
\hline Time spent learning-mathematics & $.019 * *$ & .006 & 10.871 & 3.297 & 1.019 & 1.008 & 1.030 \\
\hline Time spent learning_literacy & $-.022 * *$ & .007 & 10.011 & 3.164 & .978 & .965 & .992 \\
\hline $\begin{array}{l}\text { Results of the matriculation test-mathemat- } \\
\text { ics }\end{array}$ & $.030 * *$ & .011 & 7.933 & 2.816 & 1.031 & 1.009 & 1.053 \\
\hline
\end{tabular}

$* p<.05 ; * * p<.01$; Hosmer and Lemeshow $\chi^{2}(8)=2.643 ; \mathrm{p}$ ns.; -2 Log likelihood=233.642; Cox and Snell $\mathrm{R}^{2}=.548 ;$ Nagelkerke $\mathrm{R}^{2}=.731 ; \mathrm{AIC}=247.642$ 
The tested models fitted the data well. Predictions regarding changes in the probability of selecting study major based on the factors included in the analysis are more accurate than those based only on the intercept. Among females, significant predictors explained $73 \%$, and among males, $71 \%$, of the outcome variable variance.

Regardless of the participants' gender, the factors affecting the selection of study major were: the teacher's expectancies regarding students' achievement in mathematics and their results in the matriculation exam in this subject. In contrast, specific predictors among females were: parents' and the teacher's expectancies concerning daughters'/female students' achievement in literacy and their self-expectancies referring to achievement in mathematics and literacy, and among males: their selfconcept of mathematical and literacy abilities and time spent on learning both of these subjects. Finally, the factors that, contrary to assumptions, did not affect the outcome variable independently in the models were: parents' expectancies regarding their children's achievement in mathematics, results in the literacy section of the matriculation test, and gender of the mathematics and literacy teacher in the final grade of secondary school.

The strongest predictor in the group of females were the teacher's expectancies regarding female students' achievement in mathematics $(\exp (b)=5.388)$, and then their selfexpectancies and the teacher's expectancies concerning female students' achievement in literacy $(\exp (b)=3.622$ and .134 , respectively). In contrast, among males the three most important factors were: their self-concept of mathematical abilities $(\exp (b)=3.643)$, time spent on learning literacy $(\exp (b)=.978)$, and mathematics $(\exp (b)=1.019)$.

In terms of predictors of selecting the study major that are common to females and males, the direction of their influence was the same but the strength was different. The change of the teacher's expectancies regarding students' literacy achievement by 1 point of the scale resulted in decreasing probability of selecting a T/S major by $55 \%$ among males and by as much as $87 \%$ among females. Similarly, the increase in the result of the matriculation test in mathematics promoted to a greater extent the selection of a T/S major among males than females. The change in the test result by 10 points was associated with an increase in the probability by $135 \%$ in the first group, and by $126 \%$ in the second group.

Data presented in Table 4 points out that T/S majors selected by females were linked to the teacher's expectancies regarding female students' achievement in mathematics. Their change by 1 unit of the scale increased the chance of selecting T/S majors almost 5.5 times, which was preceded by an increase in time spent on learning mathematics and the result of the matriculation test in these subjects (correlations between these factors, $r=.212$ and $.722 ; \mathrm{ps}<.001$, respectively).

Moreover, among the predictors specific for females were: parents' expectancies concerning their daughters' achievement in mathematics and females' self-expectancies regarding achievement in mathematics and literacy with opposite vectors. The improvement of the first factor by 1 point of the scale was associated with the decrease in probability of selecting T/S majors by $73 \%$. Paradoxically, a similar change in the other two, led to a $58 \%$ decrease and a $166 \%$ increase in the probability of selecting $\mathrm{T} / \mathrm{S}$ majors.

Considering data in Table 5, the selection of T/S majors by males was significantly correlated with their effort put into learning of mathematics and literacy. The 
increase in the time of learning mathematics by every 20 min increased the probability of studying T/S by $146 \%$, which was preceded by an improvement in the result of the matriculation test in this subject (correlation between indicated predictors was $\mathrm{r}=.210 ; p<.01$ ). In contrast, increasing time spent on learning literacy by $20 \mathrm{~min}$ reduced the probability of selecting $\mathrm{T} / \mathrm{S}$ majors by $155 \%$, which was preceded by a higher result in the matriculation test in this subject (correlation between indicated predictors was $r=.283 ; p<.01)$.

Finally, the improvement of male students' self-concept of mathematical abilities by 1 point of the scale increased the chance of studying T/S majors 3.5 times. A similar change in self-concept of literacy abilities was related to a $84 \%$ decrease in the probability of selecting T/S majors.

\subsection{The teacher's gender as a moderator of study major selected by K -12 students}

The teacher's gender as a moderator of study major selected by $\mathrm{K}-12$ students was also tested. For this purpose, the product of the mathematics or literacy teacher's gender and particular predictors included in the tested models was calculated. It was then introduced to the regression equations, and eventually used to quantify to what extent it is related to the outcome variable.

Among males, out of 12 tested interactions, nine turned out to be significant. Five of them related the mathematics teacher's gender to achievement factors in this subject, i.e.: (1) the result of the matriculation test $(\exp (b)=1.025),(2)$ the teacher's expectancies $(\exp (b)=2.167),(3)$ parents' expectancies $(\exp (b)=1.868)$, (4) students' self-expectancies $(\exp (b)=1.773)$, and $(5)$ their self-concept $(\exp (b)=2.208)$. Figure 1 shows the revealed regularities.

Fig. 1 Predicted probability of selecting a T/S major dependent on the gender of the mathematics teacher and the value of the quantified predictor (males). By reference to the example of the mathematics section of the matriculation test factor. Similar function sequences were obtained for other factors related to male students' achievement in this subject, i.e.: (1) the teacher's and (2) parents' expectancies, (3) students' self-expectancies, and (4) their self-concept

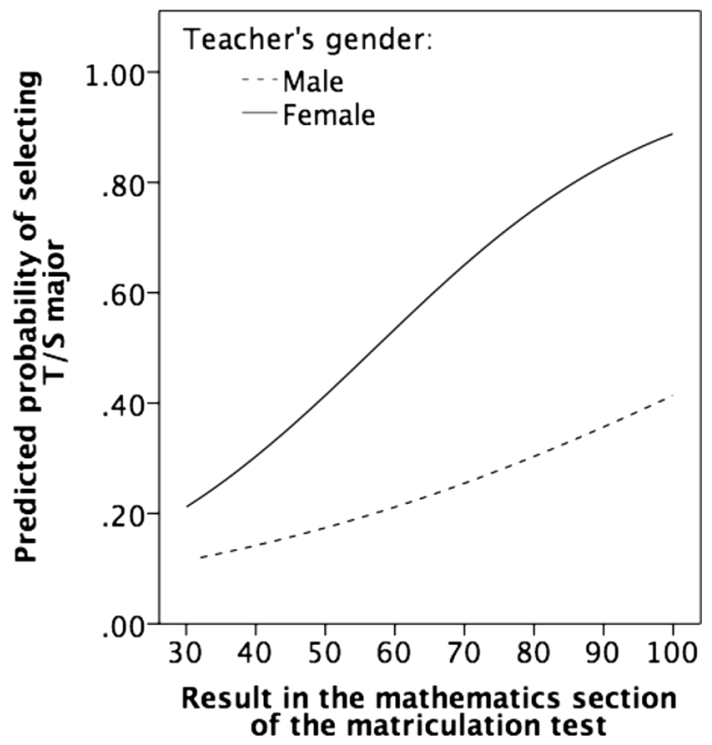


Fig. 2 Predicted probability of selecting a T/S major dependent on the gender of the literacy teacher and the value of the quantified predictor (males). By reference to the example of the student self-concept of literacy abilities. Similar function sequences were obtained for other factors related to male students' achievement in this subject, i.e.: (1) time spent on learning, (2) the teacher's and (3) parents' expectancies, and (4) students' self-concept

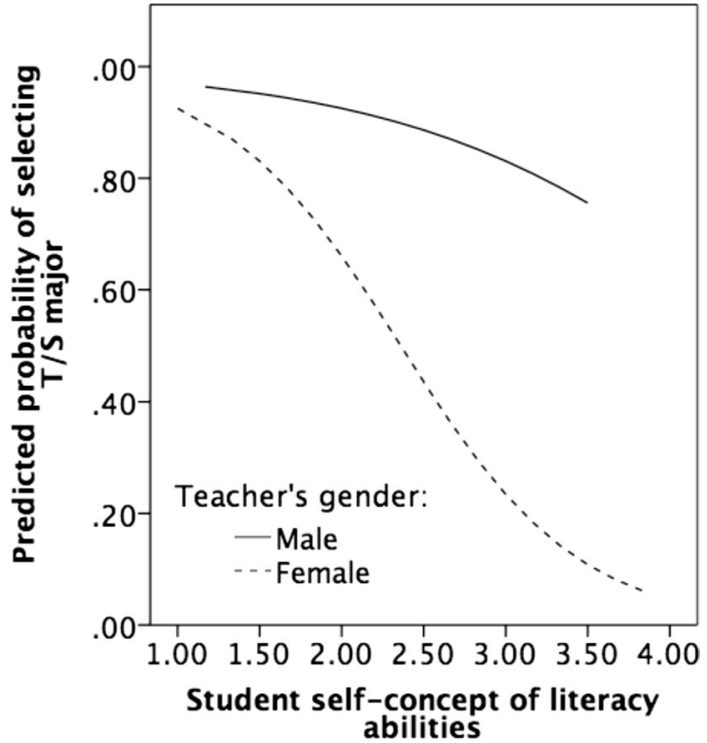

The presented profiles allow the assumption that among students with low values of the analyzed predictors, the probability of selection of T/S majors was similarly low regardless of the mathematics teacher's gender (differences from $7 \%$ for student's self-expectancies to $8 \%$ for other factors). The probability of selection increased with the improvement of the predictors' value, and it was significantly higher when the mathematics classes were taught by female than male teachers (differences from $45 \%$ for students' self-expectancies to $51 \%$ for their self-concept).

The other four interactions related the literacy teacher's gender to the predictors of students' achievement in this subject, i.e.: (6) learning time $(\exp (b)=.984),(7)$ the teacher's expectancies $(\exp (b)=.413),(8)$ parents' expectancies $(\exp (b)=.514)$, and (9) students' self-concept $(\exp (b)=.396)$. Figure 2 shows the listed interactions.

Regardless of the literacy teacher's gender, the probability of selection of T/S majors were similarly high among students with low values of indicated predictors (differences from $1 \%$ for learning time to $5 \%$ for the teacher's expectancies). The probability of selection decreased with the decrease in the value of predictors, and it was significantly lower when literacy classes were taught by female than male teachers (differences from $25 \%$ for learning time to $69 \%$ for students' self-concept).

Among females, out of 12 tested interactions, only five were significant. It is worth emphasizing that all of them related the gender of a literacy teacher to the factors of students' achievement in this subject, i.e.: (1) learning time $(\exp (b)=.982),(2)$ the teacher's expectancies $(\exp (b)=.446),(3)$ parents' expectancies $(\exp (b)=.506),(4)$ students' self-expectancies $(\exp (b)=.634)$, and $(5)$ their self-concept $(\exp (b)=.462)$. Figure 3 shows the first of these interactions.

The profiles presented in Fig. 3 indicated that greater involvement during literacy classes was related to an increase in probability of selecting T/S majors when this subject was taught by a male, and a decrease when it was taught by a female 
Fig. 3 Predicted probability of selecting T/S majors dependent on the gender of the literacy teacher and the time spent on learning literacy (females)

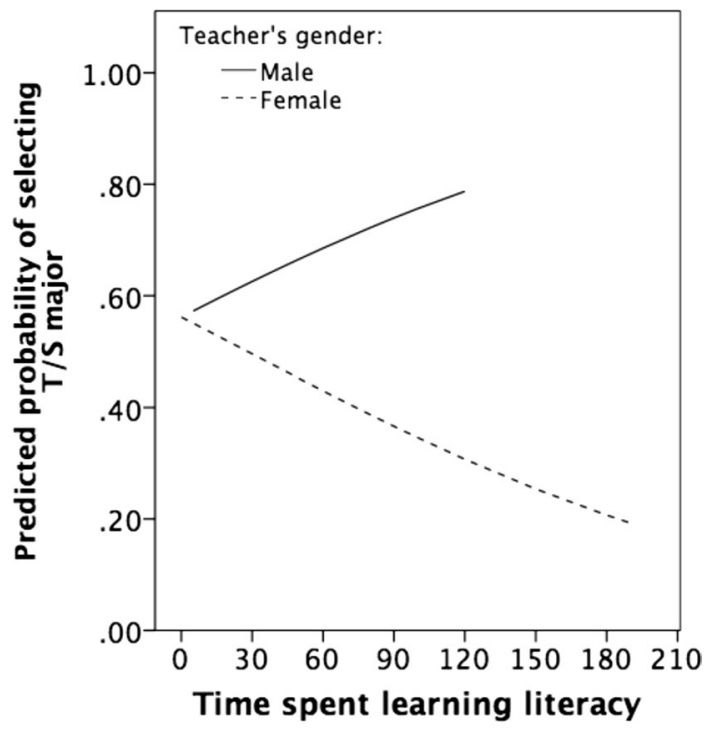

teacher (79\% and 19\%, respectively). No similar differences existed in the groups which did not put much effort into learning literacy (56\% and 55\%, respectively).

Finally, the profiles of interactions from 2 to 5 were as shown in Fig. 2. Therefore, they can be interpreted in the same way as the interactions from 6 to 9 that were found in the group of male students. Differences among female students with low versus high values of the analyzed predictors ranged from $1 \%$ for students' self-expectancies to $4 \%$ for the teacher's expectancies, and from $14 \%$ for students' self-concept to $58 \%$ for the teacher's expectancies, respectively.

\section{Discussion of results}

The goals of this study were: (1) to identify factors affecting the selection of T/S versus H/SS majors by females and males, and (2) to assess mathematics and literacy teacher gender as a moderator of relationships between the predictors included in the models and the study majors selected by females and males.

Among females, the selection of H/SS, i.e., gender-stereotyped majors, was, on the one hand, promoted by the teacher's and parents' high expectancies concerning female students/daughters' achievement in literacy and, paradoxically, by their self-expectancies regarding achievement in mathematics; and on the other hand, by the teacher's low expectancies concerning female students achievement in mathematics, the result of the matriculation test in this subject, and, surprisingly, by their self-expectancies concerning achievement in literacy.

Among males, the selection of stereotypical, i.e.: T/S majors, on the one hand, was enhanced by high values of self-concept of mathematical abilities, time spent on learning mathematics and, consequently, the result of the matriculation test in this subject; and on the other hand, by low values of the teacher's expectancies 
regarding male students' achievement in literacy, their self-concept of literacy abilities, and time spent on learning this subject.

It appears that study major selection among males was determined by a greater number of objective factors than it was among females. Considering the time spent on learning mathematics and literacy as well as the results of the matriculation test in mathematics correlated with them, male students decided to select T/S majors (reasoning: since I invested more effort in learning mathematics than literacy, which resulted in a satisfactory outcome of the matriculation test in mathematics, then T/S major will be a better choice).

On the other hand, among female students one objective predictor of study major selection was the result of the matriculation test in mathematics, although its impact was weaker than among males. Other factors were more subjective and partly gender stereotype-tinged (Jussim et al. 1996; Meece et al. 2009; Rubie-Davies 2015). Among them, the most important were the teacher's expectancies concerning female students' achievement in literacy and parents' expectancies similar in terms of the content (reasoning: since teacher and parents systematically communicate to me that I am good at literacy, then for my own sake I should select a H/SS major instead of a $\mathrm{T} / \mathrm{S}$ one). Contrary to the indicated forces were the teacher's expectancies regarding female students' outcomes in mathematics (reasoning: since the teacher claims I am good at mathematics, I will select a T/S major).

In addition to the indicated factors, the following were important among females: their self-expectancies concerning future results in mathematics and literacy. However, their impact was paradoxical and difficult to explain (bizarre reasoning: I predict that my result in the matriculation test in mathematics will be high, which tells me that I should select a H/SS major, and I think that I will easily pass the matriculation test in literacy, so I am going to select a T/S major).

In contrast, among male students the subjective factors were: self-concept of mathematical and literacy abilities. These factors, developed on the basis of personal experiences when learning specific contents, seem to be concrete, and thus, more accurate predictors of educational careers than female students' self-expectancies concerning unspecified possibilities to deal with learning mathematics or literacy in the future (Trusz 2018; Jussim 1986; Wigfield and Eccles 2000) (reasoning: I am more talented at mathematics than literacy, so I give up on a H/SS major and select a $\mathrm{T} / \mathrm{S}$ one).

Finally, considering the common predictors for the selection of study majors with the same signs in the groups of females and males, the first one, i.e., the teacher's expectancies on students' achievement in literacy, was perceived by participants as a signal confirming their predisposition to study H/SS. In turn, it had a positive impact on the selection of H/SS majors (reasoning: since the teacher communicates to me that I am gifted at literacy, it is worthwhile studying H/SS). However, their influence, according to the cultural gender-stereotype transmission model (Legewie and DiPrete 2014; Ridgeway 2011; Wang and Degot 2017; Whitley 1997) was stronger among females.

The second factor, representing the effort put into learning mathematics, was more reasonably discounted by males. After obtaining a satisfactory result in the matriculation test in this subject, they studied a similar (or related) major, being less 
prone-compared to females - to radically changing their interests (reasoning: I obtained a high result in the matriculation test in mathematics, so it would be more sensible to select a T/S than a H/SS major).

To the best knowledge of the author, so far surprisingly few studies have been conducted on the relationship between the expectancies of significant others, selfregulated learning by students' personality traits, and females' and males' preferences for H/SS or T/S majors. Existing works (e.g., Alon and DiPrete 2017; Byrne et al. 2012; Emerson et al. 2012; Walkey et al. 2013) confirm that parents' and teachers' expectancies as well as students' self-concepts, their self-expectancies, and motivation to learn are critical for educational careers of secondary school graduates, including the choice of satisfactory study majors and successful completion of the programs.

Emerson et al. (2012) point out "outside of the school, parents can contribute to their children's educational outcomes by creating a rich learning environment. Parents can discuss options for post-secondary education, stress the value of education in general, provide learning resources (...), help their children maintain positive attitudes towards their own abilities and support them through problems at school" (p. 46).

Byrne et al. (2012) add 'students' expectations of higher education often influence their choice of academic discipline as they typically seek to align their degree program with their perceived abilities, interests and personality (...) students' expectations can also impact on the learning process and their success and satisfaction within higher education" (p. 136).

Alon and DiPrete (2017) assessed gender-related selection pressure in the majors preferred by females and males. Based on data of 27,000 students the authors revealed that the egalitarian orientations of young females and males in selecting STEM majors were moderated by cultural beliefs about gender identity and differences in competencies, part of which come from the family and school environment in the form of stereotype-tinged expectancies. The indicated factors "curb the aspirations and career choices of women with the highest levels of academic competence and quantitative skills and, over time, can outweigh the effect of egalitarian forces" (p. 67).

Other studies quantified the link between the discussed factors and the students' outcomes, which in turn, are an important predictor of educational careers. Jussim and his colleagues found that the power of relationship between teachers' expectancies and students' marks in mathematics ranged from $\beta=.10$ to .49 (Smith et al. 1999), while for mathematics test results it ranged from $\beta=.09$ (Smith et al. 1999) to .21 (Jussim and Eccles 1992). Other authors reported even higher results than values quantified in meta-analyses (Hattie 2009; Rosenthal 1997), e.g., $\beta=.40$ (Gill and Reynolds 1999) and .54 (Trusz 2018).

Parents' expectancies have a similar function. Tomasetto et al. (2011) found lower mathematics achievement among female students aged 5-7 years old, if their mothers endorsed negative gender stereotypes about mathematics. Eccles et al. (1990) analyzed the relationship between parents' expectancies concerning their children's mathematics and sport competences and their cognitive and physical activity. 
Children's competences in these areas have been influenced by parents' stereotype colored beliefs about which gender is more talented in these areas.

Moreover, Garcia (2014) documented that the relationship between parents' expectancies and their children's academic achievement is modified by parents' educational/socio-economic level. As the indicated moderators increased, the strength of the link between parents' expectancies and academic achievements of children increased $(\beta=.005 ; \mathrm{p}$ ns and $.116 ; p<.05$ for parents with less than and at least a high school diploma, respectively).

Considering students' intrapersonal expectancies, their self-concepts, and motivation to learn mathematics versus literacy, research results (Buckley 2016; Cunningham et al. 2015) have shown that compared to males, lower percentages of female secondary school graduates reported that they liked mathematics or science and that mathematics or science was their favorite subjects. Moreover, higher percentages of males than females took advanced courses in science or formal sciences. Consequently, males had higher average results in the mathematics and science part of National Assessment of Educational Progress than females (Cunningham et al. 2015).

As the age of students increases, the gender gap referring to self-efficacy and the assessment of the importance of STEM majors exacerbates (Meece et al. 2009), and therefore secondary school female graduates with high outcomes in mathematics are less likely to opt for a STEM university program than male graduates (Hongo 2013). On the other hand, male graduates are more likely to select a STEM program, even in lower-mark categories. Moreover, female college students had negative beliefs about mathematics if the college environment maintained or reinforced gender stereotypes about this subject (Good et al. 2008). Finally, female students reported significantly higher levels of mathematics anxiety than male students, which may encourage them to select H/SS rather than T/S majors (Buckley 2016).

In summary, the obtained results are generally consistent with those reported by other authors and show that parents and teachers tend to perceive females to be less competent than males in mathematics-oriented majors that are perceived as masculine, and to assess as less important for female students' future educational paths than male students. These gender stereotype-tinged communications could be internalized by students and shape gender identities, that in turn may contribute to gender differences in academic interests of females and males. Furthermore, the indicated relations can be modified by teachers' gender.

In the current study, the number of significant interactions of the teacher's gender factor with predictors included in the models was higher among males (9 out of 12) than females (5 out of 12). Apparently, the educational choices of the former were more sensitive to teachers' gender than in the case of the latter. Further, among female students, the gender of the mathematics teacher was not a significant moderator in any of the tested settings, as opposed to the gender of literacy teachers (five significant interactions).

In the case of male students' relations with teachers of a different gender, and taking into account the high values of specific predictors, the probability of selecting $\mathrm{T} / \mathrm{S}$ majors was higher than for relations with teachers of the same gender. Among them were (1) the teacher's and (2) parents' expectancies concerning male students/ 
sons' achievement in mathematics, (3) students' self-expectancies, (4) self-concept, and (5) the result in the matriculation test in the subject. In these settings, female teachers were more involved in the transmission of gender stereotypes as compared to male teachers.

Similarly, in the case of female students' relations with teachers of the opposite gender, and taking into account the high values of specific factors, the odds of selecting H/SS majors were higher than for relations with teachers of the same gender. Among them were (1) the teacher's and (2) parents' expectancies concerning female students/daughters achievement in literacy, (3) their self-expectancies, (4) self-concept, and (5) time spent on learning the subject. Again, in the indicated circumstances, female teachers were more involved in the transmission of gender stereotypes as compared to male teachers.

Finally, considering male students' relations with female teachers, and taking into account the high values of specific predictors, the probability of selecting H/SS majors was higher than for male teachers. Among them were (1) the teacher's and (2) parents' expectancies concerning male students' achievement in literacy, (3) students' self-concept, and (4) time spent on learning literacy. In this case, female teachers engaged more in the transmission of beliefs incompatible with the gender stereotype.

While discussing the obtained findings it should be stressed that the results of other studies on the effects of teacher-student gender interaction on students' school achievement are mixed and sometimes contradictory. Many of them (e.g., Burusic et al. 2012; Driessen 2007; Helbig 2012; Watson et al. 2017) reported no effects of the teacher's gender on students' academic outcomes. For example, Driessen (2007), using data from over 5000 elementary school students and their teachers, found a non-significant effect of teacher gender on the achievement, attitude, and behavior of girls and boys. Helbig (2012), based on the PIRLS data with a sample of 146,315 elementary school students from 21 countries, found that boys did not benefit from having male teachers, and only in two countries, i.e., in Austria and Romania, girls performed better if their teachers were female.

However, other studies show that the teacher's gender interacting with the students' gender has significant impact on their achievement (Good and Brophy 2008; Watson et al. 2017). Li (1999) reported that male teachers taught mathematics more effectively than female teachers, and female students attain higher scores in mathematics when they are taught by female than male teachers.

Referring to studies in which quantitative and qualitative differences in teachers' interactions with male and female students were identified, Good and Brophy (2008) note that "words of encouragement or feedback directed to boys tend to focus exclusively on their achievement striving and accomplishments, but some of what is said to girls in parallel situations focuses instead on neatness, following directions, ask more thought-provoking questions of, or provide more extensive feedback to boys in mathematics or science classes but to girls in language arts classes" (p. 266). The indicated teachers' behavior can differentiate the variables correlated with students' outcomes, and in the long run affect the choices of educational paths consistent with gender stereotypes.

In the discussed studies, analysis covered the impact of teachers' and students' gender on students' achievement rather than on the selection of study majors. 
However, such works are still missing. Assuming that the indicated factors, i.e., academic outcomes and the selection of specific study majors, are correlated, it seems that the revealed regularities at least partially explain the results obtained in the current study.

\section{Limitations, conclusions, and recommendations}

The variables in the study were controlled in a retrospective, questionnaire measurement. Therefore, the considered relations did not have to be causal as was assumed. This limitation is pointed out by many investigators conducting surveys in the social sciences (Darlington and Hayes 2016).

The indicated limitation leads to another one-namely, time spent on learning mathematics and literacy was estimated based on participants' declarations, and a few months after taking the matriculation test in both subjects. Certainly, data would have been more reliable if time spent on learning was measured daily by students over the eight-month period of the final grade in secondary school. However, even in such methodologically inflated conditions, students could overestimate/underestimate the assessment of learning time, e.g., to protect their self-esteem by means of the strategy of presenting oneself in a positive light (Rhodewalt 2008).

Third, the study did not involve any control of confounding variables that could be important for the direction or effects size of the predictors of the study majors selected by students. As Garcia (2014) points out, this kind of variable can be the level of parents' education (or more general-the cultural capital of the family environment) or personal/cognitive determinants of individual susceptibility to induce incorrect interpersonal expectancies (Cooper and Hazelrigg 1988), and consequently, the formation of the educational self-fulfilling prophecies (Trusz and Bąbel 2016; Rubie-Davies 2015).

Fourth, the paradoxical and difficult to explain results obtained for females' self-expectancies indicate that they could be incidental and reflect an uncontrolled bias of non-probability sampling. Assuming this is the case, the remaining results should be interpreted with great caution since they may be an artifact of the sampling method.

Fifth, it is difficult to discuss the results by reference to findings of other authors, because there is no research in which: the selections of study majors made by females and males are explained based on the influence of objective factors (time spent on learning mathematics and literacy, and the results of the matriculation tests in both subjects) and subjective ones (the parents' and teachers' expectancies concerning their children's/students' achievement in mathematics and literacy, students' self-expectancies, and their self-concept of mathematical and literacy abilities), considering the potentially moderating impact of mathematics and literacy teacher gender. Thus, the obtained results may reflect universal regularities occurring in the population of $\mathrm{K}-12$ students or result from the applied method of data collection, analysis, and interpretation. 
Therefore, it cannot be excluded that the source of differences in the selection of study majors among females and males were not stereotype-tinged factors, as assumed, but rather biological/evolutionary determinants. Indeed, in the impressive experiment with rhesus monkeys as participants, Hassett et al. (2008) demonstrated that the sex of monkeys significantly diversified preferences concerning their selections of "typically male" toys. The vast majority of males preferred contact with wheeled vehicles, and a minority chose plush toys. However, the reversed result pattern was not observed in female monkeys. Perhaps, as a result of biologically defined preferences of exploratory activities, human children shape the family and school environment in a way that in turn offers stimuli encouraging females and male students to select H/SS and T/S majors, respectively.

Most likely, the truth about the sources of educational preferences of females and males is somewhere in the middle. Nevertheless, these choices have serious consequences, as study major selection (e.g., engineering vs. anthropology) translates into eventual outcomes on the market in terms of employment, job match, and satisfactory earnings.

Finally, biologically or culturally conditioned transmission of the gender stereotype can be effectively overcome. This is proven by the biographies of eminent people. Michael Faraday, for example, who came from a lower social class, still managed to begin his studies in physics and then conducted intensive research on electricity and magnetism, culminating in the discovery of electromagnetic induction. Similarly, Maria Skłodowska-Curie, despite the active opposition of the authorities of her home university being reluctant to the academic development of women, conducted successful research on radioactivity, which culminated in her being awarded two (sic!) Nobel Prizes, i.e., in chemistry and physics.

Funding This work was supported by the National Science Centre in Poland (Grant No. 2012/05/D/ HS6/03350).

\section{Compliance with ethical standards}

Conflict of interest The author declare that there is no conflict of interest.

Open Access This article is licensed under a Creative Commons Attribution 4.0 International License, which permits use, sharing, adaptation, distribution and reproduction in any medium or format, as long as you give appropriate credit to the original author(s) and the source, provide a link to the Creative Commons licence, and indicate if changes were made. The images or other third party material in this article are included in the article's Creative Commons licence, unless indicated otherwise in a credit line to the material. If material is not included in the article's Creative Commons licence and your intended use is not permitted by statutory regulation or exceeds the permitted use, you will need to obtain permission directly from the copyright holder. To view a copy of this licence, visit http://creativecommons.org/licen ses/by/4.0/.

\section{References}

Alon, S., \& DiPrete, T. A. (2017). Gender differences in the formation of a field of study choice set. Sociological Science, 2, 50-81. 
Aronson, J., \& McGlone, M. S. (2009). Stereotype and social identity threat. In T. Nelson (Ed.), Handbook of prejudice, stereotyping, and discrimination (pp. 153-178). New York: Psychology Press.

Babad, E. (2009). The social psychology of the classroom. New York: Routledge.

Bernard, M. E., Keefauver, L. W., Elsworth, G., \& Naylor, F. D. (1981). Sex-role behavior and gender in teacher-student evaluations. Journal of Educational Psychology, 73, 681-696.

Brophy J. E., \& Good, T. L. (1974). Teacher-student relationships: Causes and consequences. New York: Holt, Rinehart and Winston.

Buckley, S. (2016). Gender and sex differences in student participation, achievement and engagement in mathematics. http://research.acer.edu.au/learning_processes/18. Accessed August 29, 2018.

Burusic, J., Babarovic, T., \& Seric, M. (2012). Differences in elementary school achievement between girls and boys: Does the teacher gender play a role?". European Journal of Psychology of Education, 27, 523-538.

Byrne, M., Flood, B., Hassall, T., Joyce, J., Montaño, J. L., González, J. M., et al. (2012). Motivations, expectations and preparedness for higher education: A study of accounting students in Ireland, the UK, Spain and Greece. Accounting Forum, 36, 134-144.

Catalyst. (2018). Women in science, technology, engineering, and mathematics (STEM). http://www. catalyst.org/knowledge/women-science-technology-engineering-and-mathematics-stem\#footnote34 _8j0ubdw. Accessed August 29, 2018.

Cooper, H., \& Hazelrigg, P. (1988). Personality moderators of interpersonal expectancy effects: An integrative research review. Journal of Personality and Social Psychology, 55, 937-949.

Cunningham, B. C., Hoyer, K. M., Sparks, D., \& Ralph, J. (2015). Gender differences in science, technology, engineering, and mathematics (STEM) interest, credits earned, and NAEP performance in the 12th Grade. IES National Center for Education Sciences. https://nces.ed.gov/pubs2015/20150 75.pdf. Accessed August 29, 2018.

Cvencek, D., Meltzoff, A. N., \& Greenwald, A. G. (2011). Math-gender stereotypes in elementary school children. Child Development, 82, 766-779.

Darley, J. M., \& Fazio, R. H. (1980). Expectancy confirmation processes arising in the social interaction sequence. American Psychologist, 35, 867-881.

Darlington, R. B., \& Hayes, A. F. (2016). Regression analysis and linear models: Concepts, application and implementation. New York: The Guilford Press.

de Boer, H., Bosker, R. J., \& van der Werf, M. P. C. (2010). Sustainability of teacher expectation bias effects on long-term student performance. Journal of Educational Psychology, 102, 168-179.

Debacker, T. K., \& Nelson, R. M. (2000). Motivation to learn science: Differences related to gender, class type, and ability. Journal of Educational Research, 93, 245-254.

Driessen, G. (2007). The feminization of primary education: Effects of teachers' sex on pupil achievement, attitudes and behaviour. Review of Education, 53, 183-203.

Eagly, A. H. (2009). The his and hers of prosocial behavior: An examination of the social psychology of gender. American Psychologist, 64, 644-658.

Eagly, A. H., Johannesen-Schmidt, M. C., \& Van Engen, M. L. (2003). Transformational, transactional, and laissez-faire leadership styles: A meta-analysis comparing women and men. Psychological Bulletin, 129, 569-591.

Eccles, J., Jacobs, J. E., \& Harold, R. D. (1990). Gender role stereotypes, expectancy effects, and parents' socialization of gender differences. Journal of Social Issues, 46, 183-201.

Else-Quest, N. M., Hyde, J. S., \& Linn, M. C. (2010). Cross-national patterns of gender differences in mathematics: A meta-analysis. Psychological Bulletin, 136, 103-127.

Emerson, L., Fear, J., Fox, S., \& Sanders, E. (2012). Parental engagement in learning and schooling. https ://www.aracy.org.au/publications-resources/command/download_file/id/7/filename/Parental_engag ement_in_learning_and_schooling_Lessons_from_research_BUREAU_ARACY_August_2012. pdf. Accessed August 29, 2018.

Eurostat. (2017). Tertiary education statistics. http://ec.europa.eu/eurostat/statistics-explained/index.php/ Tertiary_education_statistics. Accessed August 29, 2018.

Fan, W. (2011). Social influences, school motivation and gender differences: An application of the expectancy-value theory. Educational Psychology, 31, 157-175.

Fiedler, K., Walther, E., Freytag, P., \& Plessner, H. (2002). Judgment biases in a simulated classroom-A cognitive-environmental approach. Organizational Behavior and Human Decision Processes, 88, $527-561$.

Garcia, J. N. (2014). Teacher and parent beliefs and expectations of parental involvement and how it relates to student academic achievement. $\mathrm{PhD}$ diss.: Texas State University. 
Gentrup, S., \& Rjosk, C. (2018). Pygmalion and the gender gap: Do teacher expectations contribute to differences in achievement between boys and girls at the beginning of schooling? Educational Research and Evaluation, 24, 295-323.

Gill, S., \& Reynolds, A. J. (1999). Educational expectations and school achievement of urban African American children. Journal of School Psychology, 37, 403-424.

Good, C., Aronson, J., \& Harder, J. A. (2008). Problems in the pipeline: Stereotype threat and women's achievement in high-level math courses. Journal of Applied Developmental Psychology, 29, 17-28.

Good, T. L., \& Brophy, J. E. (2008). Looking in classrooms (10th ed.). New York: Pearson.

Hall, J. A., \& Briton, N. J. (1993). Gender, nonverbal behavior, and expectations. In P. D. Blanck (Ed.), Interpersonal expectations: Theory, research, and applications (pp. 276-295). New York: Cambridge University Press.

Harris, M. J., \& Rosenthal, R. (1985). Mediation of interpersonal expectancy effects. 31 meta-analyses. Psychological Bulletin, 97, 363-386.

Hassett, J. M., Siebert, E. R., \& Wallen, K. (2008). Sex differences in rhesus monkey toy preferences parallel those of children. Hormones and Behavior, 54, 359-364.

Hattie, J. (2009). Visible learning: A synthesis of over 800 meta-analyses relating to achievement. New York: Routledge.

Helbig, M. (2012). Boys do not benefit from male teachers in their reading and mathematics skills: Empirical evidence from 21 European Union and OECD countries. British Journal of Sociology of Education, 33, 661-677.

Hongo, D. (2013). Gender differences in science, technology, engineering, mathematics and computer science (STEM) programs at university. Statistics Canada. https://www150.statcan.gc.ca/n1/ pub/75-006-x/2013001/article/11874-eng.htm. Accessed August 29, 2018.

Huang, C. (2013). Gender differences in academic self-efficacy: A meta-analysis. European Journal of Psychology of Education, 28, 1-35.

Hyde, J. S. (1990). Meta-analysis and the psychology of gender differences. Signs: Journal of Women in Culture and Society, 16, 55-73.

Hyde, J. S. (2005). The gender similarities hypothesis. American Psychologist, 60, 581-592.

Hyde, J. S. (2014). Gender similarities and differences. Annual Review of Psychology, 65, 373-398.

Hyde, J. S., Fennema, E., \& Lamon, S. J. (1990). Gender differences in mathematics performance: A meta-analysis. Psychological Bulletin, 107, 139-155.

Hyde, J. S., \& Linn, M. C. (1988). Gender differences in verbal ability: A meta-analysis. Psychological Bulletin, 104, 53-69.

Jacobs, J. E., Davis-Kean, P., Bleeker, M., Eccles, J., \& Malanchuk, O. (2004). “I can, but I don't want to" The impact of parents, interests, and activities on gender differences in math. In A. M. Gallagher \& J. C. Kaufman (Eds.), Gender differences in mathematics: An integrative psychological approach (pp. 246-263). Cambridge: Cambridge University Press.

Jussim, L. (1986). Self-fulfilling prophecies. A theoretical and integrative review. Psychological Review, 93, 429-445.

Jussim, L., \& Eccles, J. (1992). Teacher expectations II: Construction and reflection of student achievement. Journal of Personality and Social Psychology, 63, 947-961.

Jussim, L., \& Eccles, J. (1995). Naturally occurring interpresonal expectancies. In N. Eisenberg (Ed.), Social development: Review of personality and social psychology (pp. 74-108). Thousand Oaks, CA: Sage.

Jussim, L., Eccles, J., \& Madon, S. (1996). Social perception, social stereotypes, and teacher expectations: Accuracy and the quest for the powerful self-fulfilling prophecy. Advances in Experimental Social Psychology, 28(C), 281-388.

Kite, M. E., \& Whitley, B. E. (2016). Psychology of prejudice and discrimination (3rd ed.). New York: Routledge.

Kling, K. C., Hyde, J. S., Showers, C. J., \& Buswell, B. N. (1999). Gender differences in self-esteem: A meta-analysis. Psychological Bulletin, 125(4), 470-500.

Legewie, J., \& DiPrete, T. A. (2014). The high school environment and the gender gap in science and engineering. Sociology of Education, 87, 259-280.

Li, Q. (1999). Teachers' beliefs and gender differences in mathematics: A review. Educational Research, 41, 63-76.

Lindberg, S. M., Hyde, J. S., Petersen, J. L., \& Linn, M. C. (2010). New trends in gender and mathematics performance: A meta-analysis. Psychological Bulletin, 136, 1123-1135. 
Machin, S., \& Pekkarinen, T. (2008). Assessment: Global sex differences in test score variability. Science, 322, 1331-1332.

McKown, C., \& Weinstein, R. S. (2002). Modeling the role of child ethnicity and gender in children's differential response to teacher expectations. Journal of Applied Social Psychology, 32, 159-184.

Meece, J. L., Glienke, B. B., \& Askew, K. (2009). Gender and motivation. In K. R. Wentzel \& A. Wigfield (Eds.), Handbook on motivation at school (pp. 411-432). New York: Routledge.

Nguyen, H. H., \& Ryan, A. M. (2008). Does stereotype threat affect test performance of minorities and women? A meta-analysis of experimental evidence. Journal of Applied Psychology, 93, 1314-1334.

Pajares, F., \& Miller, M. D. (1994). Role of self-efficacy and self-concept beliefs in mathematical problem solving: A path analysis. Journal of Educational Psychology, 86, 193-203.

Plante, I., O'Keefe, P. A., Aronson, J., Fréchette-Simard, C., \& Goulet, M. (2019). The interest gap: How gender stereotype endorsement about abilities predicts differences in academic interests. Social Psychology of Education, 22, 227-245.

Reilly, D. (2012). Gender, culture, and sex-typed cognitive abilities. PLoS ONE. https://doi.org/10.1371/ journal.pone.0039904.

Rhodewalt, F. (2008). Self-handicapping: On the self-perpetuating nature of defensive behavior. Social and Personality Psychology Compass, 2, 1255-1268.

Ridgeway, C. L. (2011). Framed by gender: How gender inequality persists in the modern world. Oxford: Oxford University Press.

Robnett, R. D. (2016). Gender bias in stem fields: Variation in prevalence and links to stem self-concept. Psychology of Women Quarterly, 40, 65-79.

Rosenthal, R. (1997). Interpersonal expectancy effects: A forty-year perspective (p. 16). Chicago, August: Paper presented at The American Psychological Association convention.

Rubie-Davies, C. M. (2006). Teacher expectations and student self-perceptions: Exploring relationships. Psychology in the Schools, 43, 537-552.

Rubie-Davies, C. M. (2015). Becoming a high expectation teacher: Raising the bar. New York: Routledge.

Rudman, L. A., \& Phelan, J. E. (2010). The effect of priming gender roles on women's implicit gender beliefs and career aspirations. Social Psychology, 41(3), 192-202.

Schmader, T. (2002). Gender identification moderates stereotype threat effects on women's math performance. Journal of Experimental Social Psychology, 38, 194-201.

Shapiro, J. R., \& Williams, A. M. (2012). The role of stereotype threats in undermining girls' and women's performance and interest in stem fields. Sex Roles, 66, 175-183.

Simpkins, S. D., Davis-Kean, P. E., \& Eccles, J. (2006). Math and science motivation: A longitudinal examination of the links between choices and beliefs. Developmental Psychology, 42, 70-83.

Simpkins, S. D., Estrella, G., Gaskin, E., \& Kloberdanz, E. (2018). Latino parents' science beliefs and support of high school students' motivational beliefs: Do the relations vary across gender and familism values? Social Psychology of Education, 21, 1203-1224.

Smith, A. E., Jussim, L., \& Eccles, J. (1999). Do self-fulfilling prophecies accumulate, dissipate, or remain stable over time? Journal of Personality and Social Psychology, 77, 548-565.

Spencer, S. J., Steele, C. M., \& Quinn, D. M. (1999). Stereotype threat and women' s math performance. Journal of Experimental Social Psychology, 35, 4-28.

Stangor, C. (2009). The study of stereotyping, prejudice, and discrimination within social psychology: A quick history of theory and research. In T. D. Nelson (Ed.), Handbook of prejudice, stereotyping, and discrimination (pp. 1-22). New York: Psychology Press.

Starr, C. R., \& Leaper, C. (2019). Do adolescents' self-concepts moderate the relationship between STEM stereotypes and motivation? Social Psychology of Education, 22, 1109-1129.

Sullivan, A. (2009). Academic self-concept, gender and single-sex schooling. British Educational Research Journal, 35, 259-288.

Szumski, G., \& Karwowski, M. (2019). Exploring the Pygmalion effect: The role of teacher expectations, academic self-concept, and class context in students' math achievement. Contemporary Educational Psychology. https://doi.org/10.1016/j.cedpsych.2019.101787.

Tiedemann, J. (2000). Parents' gender stereotypes and teachers' beliefs as predictors of children's concept of their mathematical ability in elementary school. Journal of Educational Psychology, 92, 144-151.

Tomasetto, C., Alparone, F. R., \& Cadinu, M. (2011). Girls' math performance under stereotype threat: The moderating role of mothers' gender stereotypes. Developmental Psychology, 47, 943-949. 
Tosto, M. G., Asbury, K., Mazzocco, M., Petrill, S. A., \& Kovas, Y. (2016). From classroom environment to mathematics achievement: The mediating role of self-perceived ability and subject interest. Learning and Individual Differences, 50, 260-269.

Trusz, S. (2018). Four mediation models of teacher expectancy effects on students' outcomes in mathematics and literacy. Social Psychology of Education, 21, 257-287.

Trusz, S., \& Bąbel, P. (Eds.). (2016). Intrapersonal and interpersonal expectancies. New York: Routledge.

Voyer, D. (2011). Time limits and gender differences on paper-and-pencil tests of mental rotation: A meta-analysis. Psychonomic Bulletin \& Review, 18, 267-277.

Voyer, D., \& Voyer, S. D. (2014). Gender differences in scholastic achievement: A meta-analysis. Psychological Bulletin, 140, 1174-1204.

Voyer, D., Voyer, S., \& Bryden, M. P. (1995). Magnitude of sex differences in spatial abilities: A metaanalysis and consideration of critical variables. Psychological Bulletin, 117, 250-270.

Walkey, F. H., McClure, J., Meyer, L. H., \& Weir, K. F. (2013). Low expectations equal no expectations: Aspirations, motivation, and achievement in secondary school. Contemporary Educational Psychology, 38, 306-315.

Wang, M.-T., \& Degot, J. L. (2017). Gender gap in science, technology, engineering, and mathematics (STEM): Current knowledge, implications for practice, policy, and future directions. Educational Psychology Review, 29, 119-140.

Watson, P. W., Rubie-Davies, C. M., Meissel, K., Peterson, E. R., Flint, A., Garrett, L., et al. (2017). Teacher gender, and expectation of reading achievement in New Zealand elementary school students: Essentially a barrier? Gender and Education. https://doi.org/10.1080/09540253.2017.14101 08 .

Weathington, B. L., Cunningham, C. J., \& Pittenger, D. J. (2010). Research methods for the behavioral and social sciences. Hoboken, NJ: Wiley.

Wentzel, K. R., \& Wigfield, A. (Eds.). (2009). Handbook on motivation at school. New York: Routledge.

Whitley, B. E. (1997). Gender differences in computer-related attitudes and behavior: A meta-analysis. Computers in Human Behavior, 13, 1-22.

Wigfield, A., \& Eccles, J. (2000). Expectancy-value theory of achievement motivation. Contemporary Educational Psychology, 25, 68-81.

Publisher's Note Springer Nature remains neutral with regard to jurisdictional claims in published maps and institutional affiliations.

Sławomir Trusz Ph.D., is a Professor of Pedagogy and Head of Educational Microprocesses Laboratory at the Pedagogical University of Kraków, Poland. His leading areas of interest are the effects of intraand interpersonal expectancies and educational self-fulfilling prophecy mechanism. His recent studies focused on stereotyping, prejudice, and discrimination in relation to children with oncological disease. He co-authored the book entitled Intrapersonal and interpersonal expectancies, Routledge, 2016 (with Przemysław Bąbel, Jagiellonian University in Poland). 